\title{
Effects of anthropogenic activities on the heavy metal levels in the clams and sediments in a tropical river
}

\begin{abstract}
The present study aimed to assess the effects of anthropogenic activities on the heavy metal levels in the Langat River by transplantation of Corbicula javanica. In addition, potential ecological risk indexes (PERI) of heavy metals in the surface sediments of the river were also investigated. The correlation analysis revealed that eight metals (As, $\mathrm{Co}, \mathrm{Cr}, \mathrm{Fe}, \mathrm{Mn}, \mathrm{Ni}, \mathrm{Pb}$ and $\mathrm{Zn}$ ) in total soft tissue (TST) while five metals (As, Cd, Cr, Fe and $\mathrm{Mn}$ ) in shell have positively and significantly correlation with respective metal concentration in sediment, indicating the clams is a good biomonitor of the metal levels. Based on clustering patterns, the discharge of dam impoundment, agricultural activities and urban domestic waste were identified as three major contributors of the metals in Pangsun, Semenyih and Dusun Tua, and Kajang, respectively. Various geochemical indexes for a single metal pollutant (geoaccumulation index $\left(I_{\text {geo }}\right)$, enrichment factors $(E F)$, contamination factor $\left(C_{\mathrm{f}}\right)$ and ecological risk $(E r)$ ) all agreed that $\mathrm{Cd}, \mathrm{Co}, \mathrm{Cr}, \mathrm{Cu}, \mathrm{Fe}, \mathrm{Mn}, \mathrm{Ni}$ and $\mathrm{Zn}$ are not likely to cause adverse effect to the river ecosystem, but $\mathrm{As}$ and $\mathrm{Pb}$ could pose a potential ecological risk to the river ecosystem. All indexes (degree of contamination $\left(C_{\mathrm{d}}\right)$, combined pollution index (CPI) and PERI) showed that overall metal concentrations in the tropical river are still within safe limit. River metal pollution was investigated. Anthropogenic activities were contributors of the metal pollution. Geochemical indexes showed that metals are within the safe limit.
\end{abstract}

Keyword: Anthropogenic activities; Heavy metals; Corbiculajavanica; Langat River; Ecological risk assessment 